\title{
Summitt syndrome
}

INSERM

\section{Source}

INSERM. (1999). Orphanet: an online rare disease and orphan drug data base. Summitt syndrome. ORPHA:3210

Summitt syndrome is an extremely rare disorder originally described in two brothers and characterized by mild to severe craniosynostosis and syndactyly, obesity, and normal intelligence. Acrocephaly, brachydactyly, clinodactyly, mild syndactyly of the hands and feet, genu valgum and marked obesity were later described in another patient. There have been no further descriptions in the literature since 1979. Summitt syndrome could be a variant of Carpenter syndrome. 